\title{
AKSESIBILITAS HOTEL GRAND MEGA RESORT \& SPA BALI DENGAN MALL BALI GALERIA
}

\author{
Daniel Pandu Mau dan Dinar Sukma Pramesti \\ Email: daniel.pandu@pib.ac.id dan dinar.pramesti@pib.ac.id \\ POLITEKNIK INTERNASIONAL BALI
}

\begin{abstract}
ABSTRAK
Banyaknya hotel dibangun berdekatan dengan sarana amenitas lain seperti mall dirasakan sangat berpotensi dan diminati oleh para pengguna jasa akomodasi, karena memberikan aksesibilitas yang sangat mudah dan praktis untuk menjalankan kegiatan maupun kesenangan. Penelitian ini dimaksudkan untuk membahas tentang Aksesibilitas Hotel Grand Mega Resort \& SPA Bali dengan Mall Bali Galeria. Penelitian menggunakan metode deskriptif kualitatif. Teknik pengumpulan data menggunakan metode wawancara, observasi dan studi kepustakaan. Hasil yang diperoleh yaitu bahwa aksesibilitas merupakan hal yang sangat penting yang menjadi pertimbangan bagi para pengunjung untuk memilih hotel yang akan disinggahi. Hotel Grand Mega Resort \& SPA Bali dipilih oleh pengunjung karena mempunyai daya tarik tersendiri karena konsep yang dibangun berdekatan dengan Mall Bali Galeria dan sarana amenitas lainnya.
\end{abstract}

Kata Kunci: Aksesibilitas, Hotel, Amenitas

\section{ABSTRACT}

The number of hotels built closed to supported amenities such as malls are potential and attractive for visitors. They provides an easy accessibility to the several activities and pleasures such as shopping. This study is intended to discuss the accessibility aspect of Grand Mega Resort \& SPA Bali Hotels with Bali Galeria Mall. The study used a qualitative descriptive method. The technique of collecting data uses interviews, observation and literature study. The results of this study shows that accessibility is a very important thing that became one factor for visitors to choose the hotel to be visited. Grand Mega Resort \& SPA Bali Hotel was chosen by visitors because it has its own uniqueness because its concept that was built adjacent to the Mall Bali Galeria and other facilities.

Key words: Aksesibility, Hotel, Amenities 


\section{PENDAHULUAN}

Pekembangan bisnis di Indonesia saat ini merupakan salah satu fenomena yang sangat menarik untuk dilihat, dengan adanya globalisasi dalam bidang ekonomi yang semakin membuka peluang pengusaha asing untuk turut berkompetisi dalam menjaring konsumen lokal. Zeithaml \& Bit (2003) menyatakan bahwa dampak globalisasi menyebabkan industri jasa yang terdiri dari berbagai macam industri seperti industri telekomunikasi, transportasi, perbankan, dan perhotelan berkembang dengan cepat. Perusahaan lokal yang berperan sebagai tuan rumah semakin dituntut untuk mengenali perilaku konsumen agar mampu menghadapi persaingan di era globalisasi ini. Perusahaan yang ingin bertahan harus mempunyai nilai lebih yang menjadikan perusahaan tersebut berbeda dengan perusahaan lain. Adanya nilai lebih tersebut akan semakin memberikan kepercayaan kepada calon konsumen baru maupun konsumen lama untuk bertransaksi kembali.

Dalam menjalankan usahanya, setiap perusahaan harus selalu mengamati perubahan tingkah laku konsumen sehingga dapat mengantisipasi perubahan perilaku tersebut, untuk kemudian dijadikan kajian dalam rangka memperbaiki strategi pemasarannya. Pada hakekatnya tujuan dari pemasaran adalah untuk mengetahui dan memahami sifat konsumen dengan baik sehingga produk yang ditawarkan dapat laku terjual. Engel, dkk (1994) mengungkapkan perilaku konsumen adalah suatu kegiatan individu yang secara langsung terlibat dalam mendapatkan dan mempergunakan barang atau jasa temasuk didalamnya proses pengambilan keputusan pada persiapan dan penentuan kegiatan tersebut.

Industri perhotelan adalah industri jasa yang memadukan antara produk dan layanan. Produk hotel yang dimaksud berupa desain bangunan, kamar, restaurant beserta segala fasilitas yang ada di hotel 
tersebut. Sedangkan layanan jasa yang dijual adalah keramah-tamahan dan ketrampilan staff/karyawan hotel dalam melayani tamu yang menginap atau menggunakan fasilitas hotel. Kotler dan Amstrong (2005) mendefinisikan jasa sebagai aktivitas atau manfaat yang ditawarkan oleh satu pihak lain yang pada dasarnya tanpa wujud dan tidak menghasilkan kepemilikan apapun (intangible).

Fungsi hotel awalnya hanya sebagai tempat bermalam bagi wisatawan yang melakukan perjalanan bisnis atau berlibur. Namun seiring berjalannya waktu, fungsi hotel mengalami peningkatan. Hotel adalah usaha komersial yang menyediakan tempat menginap, makanan, dan pelayanan-pelayanan lain untuk umum (Sulastiyono, 2006). Saat ini, hotel memiliki fungsi lain selain sebagai tempat tinggal sementara untuk wisatawan yakni digunakan dalam acara pernikahan, rapat perusahaan, launching untuk produk baru suatu perusahaan dan tak jarang pula hotel digunakan untuk sarana untuk menikmati akhir pekan bagi kalangan masyarakat menengah atas. Dengan adanya perubahan fungsi hotel, para pengusaha yang bergerak di industri perhotelan diharapkan tanggap dan memiliki respon yang cepat terhadap perubahan yang terjadi.

Banyak hal yang dapat mempengaruhi usaha perhotelan saat ini, salah satunya adalah bagaimana pihak hotel dapat menarik pelanggan sebanyak mungkin. Kemudahan aksesibilitas bagi wisatawan merupakan syarat utama yang harus dimiliki karena keinginan serba cepat dan praktis bagi para pengguna merupakan salah satu modal dan kelebihan yang harus dimiliki oleh para penyedia jasa hotel. Fasilitas dan lokasi yang strategis dan kemudahan yang dicapainya suatu hotel sangat mempengaruhi keinginan para wisatawan untuk datang dan menginap pada hotel tersebut.

Saat ini banyak hotel yang dibangun berdekatan dengan fasilitas lain seperti pusat perbelanjaan karena memiliki daya tarik yang kuat 
untuk menarik wisatawan untuk menggunakan jasa hotel tersebut karena memberikan aksesibilitas yang sangat mudah dan praktis untuk menjalankan kegiatan maupun kesenangan. Terutama dari sudut pandang pembangun sarana akomodasi yang menjadi keputusan pengembang guna melakukan ekspansi bisnis adalah potensi dan kuatnya permintaan pasar (market demand). Penelitian ini mengambil konsep market demandi dimana nantinya penelitian ini akan mendeskripsikan keuntungan posisi Hotel Grand Mega Resort \& SPA Bali yang terletak berdekatan dengan Mall Bali Galeria sebagai salah satu pusat perbelanjaan tersbesar di Kuta.

Di tengah situasi ekonomi pariwisata yang kondusif di daerah Sunset Road. Daerah tersebut merupakan tempat yang cukup ramai dengan kegiatan pariwisata. Dimana terdapat beberapa hotel, salah satunya adalah Hotel Grand Mega Resort dan SPA. Hotel ini dipilih sebagai tempat melakukan penelitian karena banyak wisatawan yang memilih menginap di hotel ini, berdasarkan observasi peneliti, pusat perbelanjaan yang paling dekat dengan Hotel Grand Mega Resort dan SPA, yaitu Mall Bali Galeria. Selain itu, belum banyak penelitian yang mengkaji mengenai aksesibilitas hotel. Kebanyakan penelitian yang ada hanya membahas aksesibilitas daerah tujuan wisata.

Dari pemaparan diatas maka penelitian ini dimaksudkan untuk membahas tentang Aksesibilitas Hotel Grand Mega Resort \& SPA Bali dengan Mal Bali Galeria. Hotel bintang 4 pertama di Bali ini mempunyai daya tarik tersendiri mulai dari konsep yang dibangun berdekatan dengan Mall Bali Galeria yang merupakan pusat perbelanjaan yang telah memiliki nama besar di Bali. Permasalahan dalam penelitian ini, adalah: 1) Apa Komponen Aksesibilitas Hotel Grand Mega Resort dan Spa Bali? 2) Bagaimana Strategi Pengembangan Aksesibilitas Hotel Grand Mega Resort dan Spa Bali?. Adapun tujuan penelitian ini adalah untuk menganalisis komponen aksesibilitas Hotel Grand Mega Resort dan SPA 
Bali dan menganalisis strategi pengembangan aksesibilitas Hotel Grand Mega Resort dan SPA Bali.

\section{KONSEP DAN TEORI}

Berikut dijelaskan konsep dan teori penelitian Aksesibilitas Hotel Grand Mega Resort \& Spa Bali dengan Mall Bali Galeria

\subsection{KONSEP AKSESIBILITAS}

Bambang sutantono (2004: 1) menyatakan aksesibilitas adalah hak atas akses yang merupakan layanan kebutuhan yang mendasar dalam melakukan perjalanan. Aksesibilitas harus disediakan oleh pemerintah dengan moda transportasi untuk masyarakat. Bambang Susantono (2004: 24) juga mengungkapkan bahwa aksessibilitas merupakan suatu ukuran potensial atau kemudahan bagi seseorang untuk mencapai tujuan dalam suatu perjalanan. Karekteristik dari sistem transportasi ditentukan oleh aksesibilitas. Aksesibilitas memberikan pengaruh pada beberapa lokasi kegiatan. Lokasi kegiatan juga memberikan pengaruh pada pola perjalanan dalam melakukan kegiatan sehari-hari. Pola perjalanan ini mempengaruhi jaringan transportasi dan juga akan memberikan pengaruh pada sistem transportasi secara keseluruhan.

Sejalan dengan pendapat yang dikemukakan oleh Bambang Sutanto, Blunden dan Black (1984) juga mengemukakan pendapatnya tentang aksesibilitas. Menurutnya aksesibilatas adalah konsep yang menggabungkan sistem pengaturan tata guna lahan secara geografis dengan sistem jaringan transportasi yang menghubungkannya. Aksesibilitas juga merupakan suatu ukuran kenyamanan atau kemudahan suatu lokasi tata guna lahan dalam berinteraksi satu sama lain. Aksesibiltas juga berarti mudah atau susahnya suatu lokasi dicapai melalui sistem jaringan transportasi. Aksesibilitas dapat dinyatakan dengan jarak. Jika suatu tempat berdekatan dengan tempat lain, dikatakan 
aksesibilitas antara kedua tempat tersebut tinggi. Sebaliknya, jika kedua tempat sangat berjauhan, aksesibilitas diantara keduanya dikatakan rendah. Jadi, tata guna lahan yang berbeda memiliki aksesibilitas yang berbeda pula karena aktivitas tata guna lahan tersebar dalam ruang secara tidak merata (heterogen). Dalam penelitian ini dibahas mengenai aksesibilitas antara Hotel Grand Mega Resort \& Spa Bali dengan Mall Bali Galeria.

\subsection{KONSEP HOTEL}

Salah satu sarana penting untuk memenuhi kebutuhan orang yang berpergian lebih dari 24 jam adalah hotel. Menurut Hotel Propietors Act, (1956) pengertian hotel adalah suatu perusahaan yang dikelola oleh pemiliknya dengan menyediakan pelayanan makanan, minuman dan fasilitas kamar untuk tidur kepada orang-orang yang sedang melakukan perjalanan dan mampu membayar dengan jumlah sesuai dengan pelayanan yang diterima tanpa adanya suatu perjanjian khusus. Yoeti (1982: 252), akomodasi perhotelan tidak dapat dipisahkan dengan pariwisata, tanpa kegiatan kepariwisataan dapat dikatakan akomodasi perhotelan akan lumpuh. Sebaliknya pariwisata tanpa hotel merupakan suatu hal yang tidak mungkin, apalagi kalau berbicara pariwisata sebagai suatu industri.

\subsection{KONSEP MALL}

Mall adalah kata serapan dari bahasa inggris Mall yang diterjemahkan menjadi gedung atau kelompok gedung yg berisi macammacam toko dengan dihubungkan oleh lorong/koridor (jalan penghubung). Menurut Urban Land institute (1997), Mall merupakan kelompok kesatuan komersial yang dibangun pada sebuah lokasi yang direncanakan, dikembangkan, dimulai dan diatur menjadi sebuah unit 
operasi yang berhubungan dengan lokasi, ukuran, tipe toko, dan area perbelanjaan dari unit tersebut, dan juga menyediakan parkir yang dibuat berhubungan dengan tipe dan ukuran total toko-toko.

Saat ini mal dikenal sebagai pusat perbelanjaan atau shopping center, mall juga identik dengan pola gaya hidup manusia masa kini. Perkembangan mal yang sangat pesat saat ini memberikan jalan kepada para pengusaha dan pengembang untuk membangun sarana dan prasarana yang dekat dengan mal atau pusat-pusat perbelanjaan. Persaingan pun terjadi, pada hotel. Pembangunan hotel yang berdekatan dan berhadapan dengan Mall memberikan persaingan terhadap fasilitas dan kelengkapan yang diberikan oleh setiap hotel dan semakin wisatawan untuk menginap di hotel tersebut.

\subsection{TEORI LOKASI}

Guna mengetahui aksesibilitas Hotel Grand Mega Resort \& Spa Bali dengan Mall Bali Galeria digunakan teori lokasi Tarigan (2006). Teori lokasi membahas mengenai tata ruang (spatial order) suatu kegiatan ekonomi, atau menyelidiki alokasi geografis sumber-sumber potensial, hubungan/pengaruhnya terhadap keberadaan berbagai macam usaha/kegiatan lain di bidang ekonomi maupun sosial (Tarigan, 2006: 77). Teori lokasi Tarigan banyak membahasa tentang pengaruh jarak terhadap intensitas orang dalam bepergian dari satu lokasi ke lokasi lainnya. Analisis ini dapat dikembangkan untuk melihat suatu lokasi yang memiliki daya tarik terhadap batas wilayah pengaruhnya, dimana orang masih ingin mendatangi pusat yang memiliki daya tarik tersebut. Hal ini terkait dengan besarnya daya tarik pada pusat tersebut dan jarak antara lokasi dengan pusat tersebut.

Terkait dengan lokasi maka salah satu faktor yang menentukan apakah suatu lokasi menarik untuk dikunjungi atau tidak adalah tingkat 
aksesibilitas. Tingkat aksesibilitas merupakan tingkat kemudahan dalam mencapai suatu lokasi ditinjau dari lokasi lain di sekitarnya (Tarigan, 2006: 78). Tingkat aksesibilitas dipengaruhi oleh jarak, kondisi prasarana perhubungan, ketersediaan berbagai sarana penghubung, frekuensi, tingkat keamanan dan kenyamanan dalam melalui jalur tersebut.

\section{METODE PENELITIAN}

Metode penelitian yang digunakan adalah metode penelitian kualitatif. Metode penelitian kualitatif adalah metode penelitian yang digunakan untuk meneliti kondisi obyek yang alamiah, di mana peneliti sebagai instrume kunci dan hasil penelitian lebih menekankan makna dari pada generalisasi (Sugiyono, 2007: 23). Penelitian kualitatif bertujuan untuk proses eksplorasi dan memahami makna perilaku individu dan kelompok, menggambarkan masalah sosial atau masalah kemanusiaan.

Dalam penelitian kualitatif deskriptif terdapat 3 cara yang dapat dilakukan untuk mengumpulkan data. Cara tersebut yaitu sebagai berikut.

1. Observasi bertujuan untuk mengamati subjek dan objek penelitian, sehingga peneliti dapat memahami kondisi yang sebenarnya.

2. Wawancara, Sugiyono (2007: 211), mendefinisikan wawancara sebagai pertemuan dua orang atau lebih untuk bertukar informasi dan ide melalui tanya jawab, sehingga dapat dikonstruksikan makna dalam suatu topik tersebut. Dengan wawancara, maka peneliti akan mengetahui hal-hal yang lebih mendalam tentang informan dalam menginterpretasikan situasi dan fenomena yang terjadi, dimana hal ini tidak bisa ditemukan melalui observasi. Dalam melakukan wawancara, peneliti menyiapkan instrumen penelitian berupa pertanyaan-pertanyaan tertulis untuk diajukan, dan mencatat apa yang dikemukakan oleh informan, oleh karena itu jenis wawancara yang digunakan oleh peneliti adalah wawancara terstruktur. 
3. Dokumentasi merupakan catatan peristiwa yang sudah berlalu, berbentuk tulisan, gambar, atau karya-karya monumental (Sugiyono, 2007: 213). Hasil penelitian dari observasi dan wawancara dalam penelitian ini, didukung dengan dokumen-dokumen yang diperoleh dari dokumentasi.

\section{GAMBARAN HOTEL GRAND MEGA RESORT \& SPA BALI DAN MALL BALI GALERIA}

Pada penelitian ini, akan ditelaah secara mendalam mengenai Hotel Grand Mega Resort \& Spa Bali dan Mall Galeria Bali. Hotel ini merupakan hotel berbintang 4 yang menawarkan kolam renang outdoor, perawatan pijat, dan Wi-Fi gratis. Restorannya menyajikan berbagai hidangan Indonesia dan internasional. Parkir pribadi di resort tersedia secara gratis. Hotel Grand Mega Resort \& Spa Bali didesain dengan perpaduan modern dan tradisional, semua kamar dilengkapi dengan AC, TV layar datar dan minibar. Beberapa kamar menawarkan pemandangan kolam renang. Kamar mandi suite-nya dilengkapi dengan bathtub dan shower air panas.

Mall Galeria Bali adalah kompleks perbelanjaan skala besar yang berlokasi strategis di dekat landmark Simpang Dewaruci dan bundaran di Kuta. Mall ini menawarkan area perbelanjaan dan hiburan dengan konsep mal keluarga. Didalam mall ini terdapat berbagai macam persewaan outlet seperti makanan, pakaian, perlengkapan rumah tangga, dan kebutuhan lainnya. Tidak hanya itu, didalam mall ini terdapat pula bioskop dan brand-brand ternama internasional yang siap melayani tamutamu yang datang. 

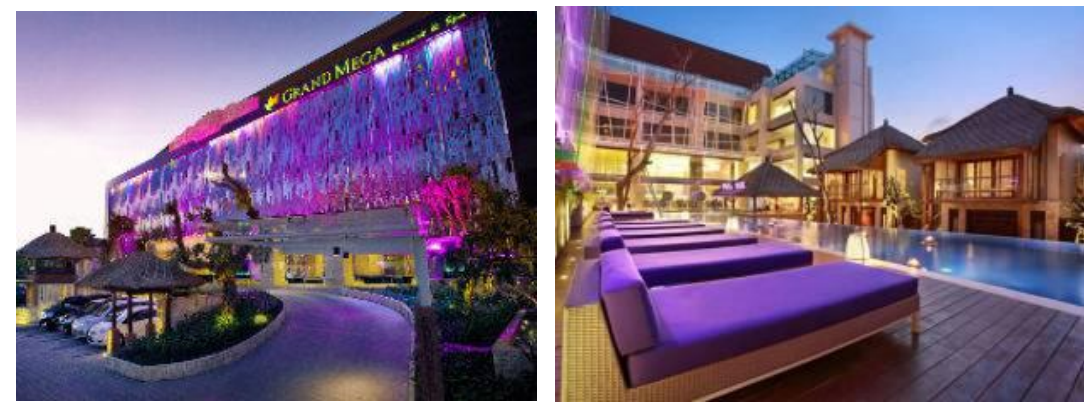

Gambar 1. Hotel Grand Mega Resort and Spa

Sumber: https://www.booking.com/hotel/id/grand-mega-resort-amp-spa-bali.id.html
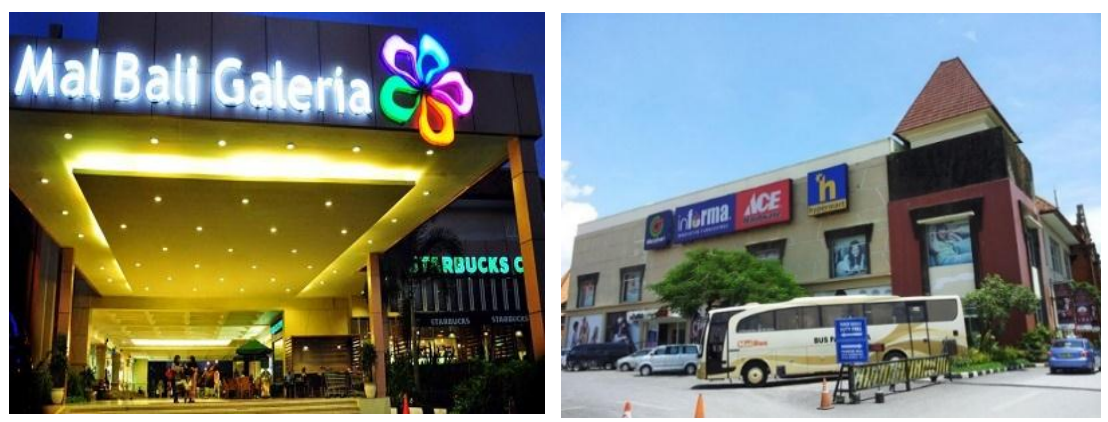

Gambar 2. Mal Bali Galeria

Sumber: https://dolandolen.com/travel-directory/mall-bali-galeria/

\section{PEMBAHASAN}

Pembahasan akan memaparkan jawaban dari masalah yang ada dalam penulisan ini, untuk lebih jelasnya dapat dilihat di bawah ini

\subsection{KOMPONEN AKSESIBILITAS HOTEL GRAND MEGA RESORT DAN SPA BALI}

Komponen aksesibilitas dipengaruhi oleh tinggi rendahnya suatu topografi daerah tertentu. Sarana dan prasarana yang berada di suatu wilayah berupa jalan, jembatan, jaringan telekomunikasi, kendaraan, terminal, pelabuhan dapat memberikan landasan terhadap kelancaran perencanaan dan pelaksanaan pembangunan dalam suatu wilayah. Aksesibilitas terkait pada seberapa mudah suatu destinasi dalam kegiatan pariwisata dapat terjangkau satu sama lain. Dalam kaitannya dengan 
penelitian ini, akan dibahas mengenai dua akomodasi antara hotel dan mall.

Aksesibilitas perhotelan berhubungan dengan tingkat kemudahan bagi seorang calon pengguna jasa untuk mencapai lokasi hotel. Pada kasus Hotel Grand Mega Resort \& SPA Bali yang berada di Jl. Bay Pass Ngurah Rai No.234, Kuta, Bali. Lokasi tersebut merupakan lokasi yang sangat strategis, J1 Bay Pass Ngurah Rai merupakan sebuah jalan raya sepanjang $23 \mathrm{~km}$ yang menghubungkan Denpasar, Sanur, Kuta, dan Nusa Dua. Jalan ini mulai beroperasi sejak 1960 dan menjadi akses utama jalur menuju Pantai Kuta dan Bandara Ngurah Rai.Jalan raya ini mempermudah akses ke bandara.

Hotel Grand Mega Resort \& Spa Bali memiliki akses yang baik dan mudah dari tempat-tempat menarik di Bali. Hotel dijangkau dengan berjalan kaki ke Bali Galleria Mall $(0,32 \mathrm{~km})$, berjarak 0,27 km dari Patung Dewa Ruci, berjarak 0,04 km dari BIMC Hospital, berjarak 3 km dari Pantai Kuta, berjarak 1,10 km dari Joger Kuta, berjarak 2,0 km pusat kota, dan berjarak 3,8 km dari bandara Ngurah Rai.

Letak yang strategis dan kemudahan akses tersebut merupakan salah satu kelebihan yang dimiliki oleh Hotel Grand Mega Resort \& SPA Bali, karena memudahkan para calon pengguna jasa untuk menemukan lokasi tersebut. Beberapa perusahaan yang berada di kawasan industri memilih dan menempatkan tamu-tamu nya di Hotel Grand Mega Resort \& SPA Bali. Wisatawan dapat menjangkau mall dari hotel hanya dengan berjalan kaki menempuh waktu sekitar 5 menit.

Kondisi jalan yang baik pun merupakan salah satu kemudahan aksesibilitas, karena dapat mempersingkat waktu dan memberikan jarak tempuh yang singkat untuk mencapai Hotel Grand Mega Resort \& SPA Bali. Kemudahan aksesibilitas yang lainnya adalah kemudahan bagi para pengguna jasa transportasi umum seperti letak halte Trans Sarbagita yang 
berada di dekat hotel. Sayangnya, sedikit kekurangan aksesibilitas antara kedua amenitas ini adalah kurangnya fasilitas jembatan umum. Wisatawan harus berhati-hati ketika menyebrang jalan dikarenakan letak kedua amenitas ini yang bersebrangan. Pihak hotel maupun mall sudah berusaha mengantisipasi ketiadaan jembatan tersebut dengan mempekerjakan satpam yang sekaligus bekerja untuk mengamankan para pejalan kaki yang ingin menyebrang. Berdasarkan hasil observasi tersebut, maka aspek aksesibilitas merupakan hal penunjang dan langkah awal yang harus dipikirkan bagi para pengusaha untuk mendirikan suatu bangunan usahanya.

\subsection{STRATEGI PENGEMBANGAN AKSESIBILITAS HOTEL GRAND MEGA RESORT DAN SPA BALI}

Berdasarkan hasil observasi, kurangnya fasilitas pendukung aksesibilitas seperti jembatan penyebrangan membuat kedua fasilitas pendukung amenitas ini sedikit sulit untuk dijangkau dengan lebih leluasa. Oleh karena hal tersebut, maka strategi pengembangan aksesibilitas Hotel Grand Mega Resort \& SPA adalah dengan menyediakan antar-jemput gratis ke Kuta dan Mall Bali Galleria. Hotel Grand Mega Resort \& SPA berseberangan dengan Mall Bali Galeria ini memudahkan para tamu untuk bekerja, mendapatkan kenyamanan dan hiburan. Pengunjung tidak perlu repot dan jauh berbelanja, menikmati makanan dan menonton bioskop. Semua fasilitas itu terdapat di Mall Bali Galeria yang merupakan mall terbesar di Bali. Hotel Grand Mega Resort \& SPA. Letaknya yang dekat dengan Mall Bali Galeria ini memberikan efek Long Stay Guest sehingga mampu memberikan sumbangan pemasukan yang cukup baik bagi Kabupaten Badung.

Aksesibilitasperhotelan berhubungan dengan tingkat kemudahan bagi seorang calon pengguna jasa untuk mencapai lokasi hotel. Hotel 
Grand Mega Resort \& SPA Bali berada di Sunset Road yang berada tidak jauh dari landmark terkenal Bali yaitu Patung Dewaruci, letak yang strategis dan kemudahan akses tersebut merupakan salah satu kelebihan yang dimiliki oleh Hotel Grand Mega Resort \& SPA Bali, karena memudahkan para calon pengguna jasa untuk menemukan lokasi tersebut. Kondisi jalan yang baik pun merupakan salah satu kemudahan aksesibilitas, karena dapat mempersingkat waktu dan memberikan jarak tempuh yang singkat untuk mencapai Hotel Grand Mega Resort \& SPA Bali. Kemudahan aksesibilitas yang lainnya adalah kemudahan bagi para pengguna jasa transportasi umum seperti letak Bandara Ngurah Rai Bali yang dapat ditempuh dengan waktu 15 menit.

Aksesibilitas merupakan hal penunjang dan langkah awal yang harus dipikirkan bagi para pengusaha untuk mendirikan suatu bangunan usahanya. Seperti halnya Hotel Grand Mega Resort \& SPA Bali yang berada pada lokasi yang cukup menguntungkan karena berada di wilayah yang merupakan pusat dari kesibukan kotaBali.

Hotel bintang 4 pertama dan satu-satu nya di kota Bali ini memberikan sumbangan pemasukan yang cukup baik bagi kota Bali. Karena dengan alasan kemudahan ditempuh dan fasilitas yang cukup memuaskan, beberapa perusahaan yang berada di kawasan industri memilih dan menempatkan tamu-tamu nya di Hotel Grand Mega Resort \& SPA Bali. Long Stay Guest memberikan pengertian bahwa Hotel Grand Mega Resort \& SPA yang memiliki konsep ini memudahkan para tamu untuk berwisata dan mendapatkan kenyamanan di lokasi tersebut.

\section{PENUTUP}

Kesimpulan yang dapat diperoleh berdasarkan hasil pengamatan di lapangan dan analisis data yaitu dengan hadirnya konsep aksesibilitas antara dua amenitas pendukung pariwisata yang berdekatan dapat 
memberikan berbagai keuntungan, yaitu dapat mempermudah dan pengguna jasa akomodasi atau tamu yang menginap di Hotel Grand Mega Resort \& SPA Bali untuk membeli kebutuhan pribadi di Mall Bali Galeria dan pengunjung Mal jika ingin menginap tidak perlu jauh dan sulit mencari, karena letaknya yang berada berdekatan. Fasilitas yang tersedia baik di Mall Bali Galeria maupun Hotel Grand Mega Resort \& SPA Bali sudah cukup memadai.

Selain memiliki akses yang mudah ke Mall Bali Galeria, Hotel Grand Mega Resort \& Spa Bali memiliki akses yang mudah ke tempattempat menarik lainnya di Bali seperti Patung Dewa Ruci, BIMC Hospital, Pantai Kuta, Joger Kuta, pusat kota, dan bandara Ngurah Rai. Hotel ini juga terletak di jalan utama dengan kondisi yang baik dan lancar. Letak yang strategis dan kemudahan akses tersebut merupakan salah satu kelebihan yang dimiliki oleh Hotel Grand Mega Resort \& SPA Bali. Berdasarkan hasil observasi tersebut, maka aspek aksesibilitas merupakan hal penunjang dan langkah awal yang harus dipikirkan bagi para pengusaha untuk mendirikan suatu bangunan usahanya.

Rekomendasi yang diberikan peneliti yaitu agar Hotel Grand Mega Resort \& SPA melakukan kerjasama dengan Mall Bali Galeria misalnya dalam memberikan discount atau membantu dalam promosi sehingga akan menguntungkan bagi keduanya.

\section{DAFTAR PUSTAKA}

Bagyono. 2008. Teori \& Praktek Hotel Front Office. Bandung: Alfabeta Baud Bovy, Fred Lawson. 1998. Tourism and Recreation Handbook of Planning and Design. London: Architectural Press.

Bintarto, R. 1984. Interaksi Desa-Kota dan Permasalahannya. Semarang: Ghalia Indonesia

Black, John. 1981. Urban Transport Planing. Croom Helm: London

Bukart, A. J and S. Medlik. 1974. Tourism: Past, Present, and Future. London. United Kingdom. 
Djumhur, I \& Surya Muh. 1981. Psychology and Education. Bandung: Bandung Lautan Api

Hansen, W.G. 1959. "How Accessibility Shapes Land Use". Journal of American Institute of Planners. Vol. 25, 73-76.

Kartini, Kartono. 1980. Pengantar Metodologi Research Sosial. Bandung: Alumni.

Sugiyono. 2012. Metode Penelitian Kuantitatif Kualitatif dan $R \& D$. Bandung: Alfabeta.

Sugiyono. 2015. Metode Penelitian Kombinasi (Mix Methods). Bandung: Alfabeta.

Sumaatmadja, N. 1988. Studi Geografi, Suatu Pendekatan \& Analisa Keruangan. Bandung: Alumni.

Suthanaya, Putu. 2009. Analisis Aksesibilitas Penumpang Angkutan Umum. Ganesha Swara Edisi Khusus. Vol. 3 No. 3 Desember 2009.

Wardiyanta. 2006. Metode Penelitian Pariwisata. Yogyakarta: Andi.

Yoeti, A. Oka. 1984. Pengantar Ilmu Pariwisata. Bandung: Angkasa Offset.

\section{STUDI INTERNET:}

Anonim. 2011. Pengertian Aksesbilitas, dalam makalah Universitas Sumatera Utara. (serial online). [cited 2010 Nov. 9]. Available from URL: http://repository.usu.ac.id/bitstream/123456789/2034 4/4/chapter\%2011.pdf.

Hasmy. 2000. Konsep-konsep Dasar Penelitian dalam makalah Universitas Pendidikan Indonesia (serial online). [cited 2016 Ags. 2]. Available from URL: http://repository.upi.edu/ operator/upload/s_c0951_06-419_chapter3.pdf.

Maghribi. 1999. Aksesibilitas Building. (serial online). [cited 2016 Jan. 10]. Available from URL: www.openpdf.com.

Moh. Surya, 1981. (serial online). [cited 2011 Nov. 9]. Available from URL: http://belajar psikolog.Com/pengertian-belajar-menurutahli/. 


\section{PROFIL PENULIS}

Daniel Pandu Mau, S.Pd.,M.Par lahir di Pangkoh, 28 Juli 1991. Menyelesaikan Pendidikan Sarjana Pendidikan Bahasa Inggris di Universitas Palangkaraya pada tahun 2013. Melanjutkan Pendidikan Magister Pariwisata di Pascasarjana Universitas Udayana tahun 2016. Saat ini sedang melanjutkan studi di Magister Manajemen Universitas Udayana. Kecintaannya pada dunia Pendidikan ini disalurkan dengan menjadi Dosen Manajemen Perhotelan di Politeknik Internasional Bali.

Dinar Sukma Pramesti, ST., MT lahir di Denpasar 12 September 1988. Menyelesaikan Pendidikan Sekolah Dasar hingga SMA di Bali. Menamatkan Sarjana Teknik Arsitektur di Universitas Udayana pada tahun 2010. Melanjutkan Pendidikan Magister di bidang arsitektur dengan mengambil konsentrasi Arsitektur Kajian Lingkungan Binaan Etnik di Pascasarjana Universitas Udayana yang diselesaikan tahun 2013. Memiliki pengalaman sebagai arsitek selama 3 tahun di sebuah perusahaan arsitek, kontraktor, konsultan dan design planning di Denpasar. Pernah bekerja selama 5 tahun sebagai asisten Prof. Dr. Ir. Sulistyawati, M.S., M.M., M.Mis., D.Th., Ph.D, seorang Profesor yang aktif dalam membuat buku dan penelitian di bidang arsitektur dan pariwisata. Pengalamannya ini membawanya menjadi Dosen D4 Manajemen Perhotelan di Politeknik Internasional Bali, mengajar mata kuliah Seni Budaya Bali dan Metodelogi Penelitian. 